A N N A L E S Annales de Bretagne et des Pays de l'Ouest

Anjou. Maine. Poitou-Charente. Touraine

$117-2 \mid 2010$

Varia

\title{
André Chédeville 1935-2010
}

\section{(2) OpenEdition}

$\checkmark$ Journals

Édition électronique

URL : http://journals.openedition.org/abpo/1800

DOI : $10.4000 / a b p o .1800$

ISBN : 978-2-7535-1518-5

ISSN : 2108-6443

Éditeur

Presses universitaires de Rennes

Édition imprimée

Date de publication : 10 juillet 2010

Pagination : 7

ISBN : 978-2-7535-1214-6

ISSN : 0399-0826

\section{Référence électronique}

«André Chédeville 1935-2010 ", Annales de Bretagne et des Pays de l'Ouest [En ligne], 117-2 | 2010, mis en ligne le 20 juillet 2010, consulté le 01 mai 2019. URL : http://journals.openedition.org/abpo/1800 ; DOI : $10.4000 / a b p o .1800$ 


\section{André Chédeville}

1935-2010

Le professeur André Chédeville s'est éteint en juin dernier. Ce brillant spécialiste de l'histoire du Moyen Âge demeure par son œuvre, autant que sa carrière, totalement attaché à l'université de Rennes 2. Nantais, il était venu terminer ses études supérieures d'histoire à Rennes auprès en particulier de Raymonde Foreville et n'avait pas tardé, après l'agrégation, à rejoindre l'université, en 1962, pour ne la quitter que lors de son départ en retraite, en 1995.

Ses recherches en ont fait d'abord un grand spécialiste de l'histoire des villes. Sa thèse sur Chartres et ses campagnes demeure une référence. Il participa ensuite à la grande synthèse de L'Histoire de la France urbaine et fit longtemps partie de la "Commission Internationale des Villes ». Il s'orienta aussi vers l'histoire de la Bretagne et dirigea la monumentale Histoire de Bretagne des éditions Ouest-France, ouvrage sans équivalent en France, tout en participant à la rédaction de deux des volumes. Cela le conduisit à présider pendant plus de 10 ans la Société d'Histoire et d'Archéologie de Bretagne qu'il sut animer et dynamiser, l'érigeant en modèle de société savante régionale. Sa contribution considérable à l'histoire de la Bretagne fut reconnue par l'Institut culturel de Bretagne qui devait lui remettre le collier de l'Hermine cet été.

Il fut aussi un enseignant remarquable, sachant capter l'attention de ses étudiants et susciter des vocations de médiévistes. Il dirigea de nombreuses thèses de doctorat et ses anciens étudiants se retrouvent aussi bien en France qu'aux État-Unis ou au Japon. Enfin, il n'oublia pas la vie de son université qui traversait des moments difficiles et devait accomplir de délicates réformes. Il consacra du temps et de l'énergie à travailler à l'émergence d'une nouvelle université en assumant nombre de responsabilités dans les conseils et occupa la lourde charge de vice-président du conseil d'administration.

Il laisse aujourd'hui à ses collègues, à ses amis, le souvenir d'un homme attentif, sachant prendre la distance nécessaire pour mesurer les problèmes en s'abritant derrière un humour qui le caractérisait pleinement. Chercheur de renom, professeur apprécié, administrateur rigoureux, il laisse à l'université de Rennes 2 et à tous, le modèle d'un grand universitaire et d'un maître dans toutes les acceptions du terme.

Daniel PICHOT 